\title{
USING CHESSBOARD TECHNIQUE IN RESPONDING TO THE SHORT STORY TO DEVELOP STUDENTS' SPEAKING SKILL
}

\author{
Putu Karolina \\ University of Sriwijaya \\ Email : putukarolina@gmail.com
}

Karolina, Putu. 2009. Using Chessboard Technique in Responding to the Short Story to Develop Students' Speaking Skill. Thesis of Undergraduate Program of English Education University of Sriwijaya. Advisor: (S2) Drs. Bambang Suwarno, M. A., Ph. D. Advisors (SI) 1. Dra. Rita Hayati, M. A., 2. DR. Rita Inderawati, M. Pd

\begin{abstract}
This study aimed to answer whether using chessboard technique in responding to short story develops student's speaking skill or not. The method used in this study was one of quasi experimental designs: pretest-posttest non-equivalent comparison control group design. The population of the study was the eleventh grade student at SMA N 12 Palembang and the sample was taken from the population by using purposive sampling. The data were collected by using two instruments, test and questionnaire. The test was given twice to the experimental and control group, as the pretest and the posttest. The questionnaire was distributed to the experimental group after conducting the treatment to get more information related to the problem of the study. To verify the hypothesis, the data from pretest and posttest on the experimental and control group were analyzed by using paired sample t-test and independent sample t-test. The result of the study showed that applying chessboard technique in responding to the short story develops student's speaking skills. Some students (60\%) in the experimental group achieve good category compared to only few students (20\%) in control group.
\end{abstract}

\section{Keywords: Chessboard Technique, Short Story, Speaking Skill.}

\begin{abstract}
Abstrak: Penelitian ini bertujuan untuk menjawab apakah menggunakan teknik chessboard dalam merespon cerita pendek dapat mengembangkan kemampuan berbicara atau tidak. Metode yang digunakan dalam penelitian ini adalah salah satu desain kuasi eksperimental. Populasi dari penelitian ini adalah kelas sebelas SMA Negeri 12 Palembang dan sample yang diambil dari populasi adalah purposive sampling. Data dikumpulkan dengan menggunakan dua instrument; test dan angket. Tes diberikan dua kali pada masing-masing kelompok eksperimen dan kelompok control yaitu pra test dan post tes. Angket disebarkan pada kelompok eksperimen setelah dilakukan treatmen untuk mendapatkan informasi mengenai masalah dalam penggunaan metode chessboard. Untuk memverifikasi hipotesa, data dari pra dan pos tes dianalisa menggunakan paired sample t-test dan independent sample t-test. Hasil penelitian menunjukkan penggunaan teknik chessboard dalam merespon cerita pendek meningkatkan kemampuan berbicara siswa. $60 \%$ siswa di kelompok eksperimen mencapai kategori baik dibandingkan hanya $20 \%$ siswa dalam kelompok control.
\end{abstract}

Kata Kunci: Teknik Chessboard, Cerita Pendek, Keahlian Berbicara. 


\section{INTRODUCTION}

It is truly undeniable that English has been a highly popular international communication instrument that it is flourishingly spoken across the universe today. Some countries use English as a second language which means people frequently speak English in real interaction besides first language. Others put English merely as a foreign language that it is only used in certain communication. While English as second language opens more opportunity for people to communicate, English as a foreign language like in Indonesia has less chance to be spoken and practice in daily interaction.

Speaking skill is an oral productive skill in which one should gather a lot of aspect in English simultaneously with what is in his mind. It seems students find speaking skill as the most difficult skill compared to other English skills. In fact, students have difficulty in speaking skill due to various reasons such as lack of selfconfidence, lack of English fluency, lack of English proficiency, and so on. In accordance to with the research done by Shinta Viana Sari, undergraduate student of English Department of Sriwijaya University, some factors that cause students to be reluctant to speak actively in English, especially English discussion are selfconfidence, English proficiency, motivation, psychological role, topic of the discussion, pattern of the discussion, and unawareness of the benefit of the discussion. The complete data could be seen on the table below:

Table 1: The Factors and Percentage Causing Students' Reluctance to Participate in English Discussion

\begin{tabular}{|l|l|l|}
\hline No & Factor & Percentage \\
\hline 1 & Student's self confidence & $14,72 \%$ \\
\hline 2 & English proficiency & $14,72 \%$ \\
\hline 3 & Motivation & $14,31 \%$ \\
\hline 4 & Psychological role & $14,16 \%$ \\
\hline 5 & Topic of the discussion & $16,22 \%$ \\
\hline 6 & Pattern of the discussion & $16,69 \%$ \\
\hline 7 & Unawareness of the benefit of the discussion & $9,32 \%$ \\
\hline
\end{tabular}

Teaching speaking highly requires teachers to be more creative and innovative. The ability to ensure students and make the situation in which students might feel confident and comfortable in speaking is necessarily needed for every teacher. Unfortunately, very few teachers are concerned with the importance of speaking skill. As a result, students lose their opportunities to explore their potential and have less chance to practice their English skill. Moreover, Lawtie (2004) states that if students do not learn how to speak or do not get any opportunity to speak in the classroom, they may soon get de-motivated and lose interest in learning. On the other hand, if the right activities are taught in the right way, speaking in class can be a lot of 
fun, raising general learner's motivation and making English language classroom a fun and dynamic place. One of ways to overcome this issue is by using literature. Literature might be enjoyable instrument for English teacher in teaching language skill including speaking. To help students improve their speaking skill through literature, Colie and Slater (1987) in their book Literature in the Language Classroom recommended some technique that can be applied by teachers in teaching to improve language skill. One of which the writer highly interested in is chessboard technique.

Chessboard, in literature teaching method, is another way of getting students to consider the implication of given element in a literary work. The procedure in chessboard is to ask student to place statement on either The White Square (for positive, 'good' elements) or Black Square (for negative or 'bad' elements) of a chessboard-shaped grid.

As has been stated before, this technique requires a literary work as medium to make the application run well. In this research the writer used short story as the instrument. One consideration that made the writer select short story is that the conflict in short story is usually not as complex or complicated as a novel has. Furthermore, it does not take much time for students to finish reading it since it could be read not more than an hour.

Chessboard technique direct teacher to put students into four groups and asks them to decide whether each statement related to the short story students just read is a good or bad thing. Then each group pins it on to a light or dark square in their sector of chessboard. If student consider any statement to have both positive and negative aspects, they are allowed to pin it on both squares, with different supporting quotes. When all four parts of the chart have been filled in, lively discussion must result from the fact that statement have been placed on opposite squares by different group. In the writer's opinion, among the four language skills, speaking is the dominant skill practiced during the application of this technique.

\section{The Concept of Chessboard}

Chessboard, in literature teaching method, is another way of getting students to consider the implication of given elements in a literary work. The procedure in chessboard is to ask students to place statement on either the white square (for positive, 'good' elements) or black squares (for negative or 'bad' elements) of a chessboard-shaped grid. This activity is designed to sharpen student's awareness of ambiguities.

The use of chessboard technique, where it requires students to talk a lot during the application, really fits to the "studentdirected" in schematic representation of oral communicative class activities above. It is dynamic task-centered activity which is designed to generate student's interest to practice a lot in English.

\section{The Concept of Short Story}

According to Wikipedia (2006) as cited in http://www.en.wikipedia.org/wiki/Shortstory, "A short story is a form of short fictional 
narrative story prose". Short story tends to be more concise and to the point than longer works of fiction, such as novellas (in the modern sense of this term) and novels. Because of their brevity, successful short story relies on literary devices such as character, plot, theme, language, and insight to a greater extent than long form fiction.

\section{The Use of a Short Story in Speaking Skill}

Short story, as one of literary works, plays a very great role in education especially in teaching English. Many researchers have showed that the use of short story influences student's curiosity in learning English. The topic provided in a short story really explores reader's personal experience that many teachers feel more eager and interested in using short story as a medium in teaching English.

\section{The Concept of Speaking Skill}

Speaking is the productive skill in the oral mode. It, like the other skill, is more complicated than just pronouncing the words (SIL International, 1999). Speaking or oral communicative skill is important for both EFL and ESL learners. It is one of the most necessary language skills for displaying their language proficiency. The ultimate aim of oral English teaching should be the acquisition of oral communicative competence, i.e., the ability to speak appropriately.

Conducting the researcher, the writer used short story as an instrument to trigger student's speaking activity in the classroom discussion. Student had a face to face interaction among them in which that listened and spoke alternatively and the possibility to ask clarification and repetition might happen during the discussion.

\section{The Use of Chessboard in Speaking}

In order to properly develop communication skill the students must be active. Furthermore, they need to think in the target language. In order to accomplish these goals they need dynamic task-centered activities designed to generate students' interest while all but eliminating the translation step. Unfortunately, so far the teaching of speaking tends to be monopolized by the traditional grammartranslation method where the teacher tends to dominate class time speaking in the native language, while student passively listen and languish.

Basically there are two big categories of activities in teaching speaking in that scheme; teacher-controlled and studentdirected. Schematic representations of class activities, which collectively represent a broad spectrum of formal teaching methodologies, are subdivided into four categories. It forms a step-by-step progression beginning with " $\mathrm{A}$ ", continuing "B", and "C", and finishing with " $D$ ". Teacher-controlled" activities generally involve the whole class with the teacher playing a pivotal role analogous to a conductor of a symphony or that of stimulator. "Students-directed" activities are done in pairs or small groups with the teacher playing the more passive role of organizer or consultant. 


\section{Method of Research}

In conducting this research, the writer used one of quasi experimental design: pretestposttest non equivalent comparison control group design. Wallen and Frankel (1991: 289) say that a quasi experimental design study is conducted when random assignment is not possible. Although two or more groups of subjects are still compared, the subjects are not randomly assigned to the treatment and control group. The basic scheme is as follow:

O1 X1 O2

O3 $\quad \mathrm{X} 2 \quad \mathrm{O} 4$

Where :

----- : : Dashed line indicated non-random assignment to comparison group

O1 : Pretest of experimental group

O2 : Posttest of the experimental group

O3 : Pretest of control group

O4 : Posttest of control group

X1 : Treatment to experimental group (Chessboard Technique)

X2 : Treatment to control group (Traditional Way)

In this research, the researcher applied the chessboard technique for sixteen meeting for the experimental group and traditional technique for control group for sixteen meetings as well.

All of the meetings was done out of learning hours. Before doing the treatment, on the first meeting, the writer gave pretest to both experimental and control group to know student's speaking skill. The test material given to both groups was definitely similar. The writer designed the test base on the curriculum of the eleventh grade student of Senior High School.

\section{Population and Sample}

Population

Population is the group to which a researcher would like to result to be generalized and which includes all individuals with certain characteristics (Wallen and Fraenkel: 1991:129). Another definition of population comes from Webster (1984:1146) who states that population is a set of individual people or items from which samples are taken for statistical measurement. The population of this research was all the eleventh-grade students of SMA N 12 Palembang with the total number of 194 students. The distribution of the whole population can be seen in the table 2 below:

Table 2: The Population of the Study

\begin{tabular}{|l|c|c|}
\hline No & Class & $\begin{array}{c}\text { Total Number of } \\
\text { the Student }\end{array}$ \\
\hline $\mathbf{1}$ & XI IPA 1 & $\mathbf{3 8}$ \\
\hline $\mathbf{2}$ & XI IPA 2 & $\mathbf{3 8}$ \\
\hline $\mathbf{3}$ & XI IPS 1 & $\mathbf{3 9}$ \\
\hline $\mathbf{4}$ & XI IPS 2 & $\mathbf{3 9}$ \\
\hline $\mathbf{5}$ & XI IPS 3 & $\mathbf{4 0}$ \\
\hline \multicolumn{2}{|c|}{ Total } & $\mathbf{2 0 7}$ \\
\hline
\end{tabular}

Source: SMA N 12 Palembang 2008/2009 Sample

Sample refers to any group on which information is obtained. Webster (1984: 1314) defines sample as a subset of a statistical population (complete set of individual, object, etc) whose properties are studied to gain information about the whole system. 
In this study the writer used purposive sampling. On occasion, using previous knowledge of population and the specific purpose of his or her research, an investigator uses personal judgment to select sample. The researcher assumes that personal knowledge of the population could be used to judge whether a particular sample was representative. (Wallen and Fraenkel, 199: 138).

There were some criteria that became the writer's judgments in selecting the sample. First, students must be taught by same English teacher. Second, the students' level of English competence must be averagely similar. In this case, the writer took students whose English score in report is 7 .

\section{Technique for Collecting the Data}

Test

In collecting the data, the writer used test. There are two kinds of test used by the writer. The first one was pretest that is given before the treatment and the other was posttest that is given after the treatment. The test in both experiment and control group was definitely the same. The pretest was given to find out students' speaking skill before the treatment, whereas, the posttest is given to find out student's speaking skill after the treatment.

\section{Questionnaires}

Questionnaire is a set of question that should be covered by the respondents in order to obtain the information about the identical data, experience, attitude, knowledge, opinion, etc (Arikunto, 1998:24). Questionnaire was distributed to the experimental group after they get the treatment and do the posttest. The writer distributed the questionnaire to each student in the experimental group in order to know their opinions and feeling about the application of chessboard in their appreciation of the short story.

\section{Technique for Data Analysis}

To assess student's speaking skill the writer used an analytical or holistic rubric. A holistic provides one overall score. An analytic rubric provides information broken down into different categories. The Students Oral Langue Observation Matrix is an analytic rubric used to assess speaking skill.

The Students Oral Langue Observation Matrix (SOLOM) is a rating scale that teachers can use to assess student's command of oral language on the basis of what they observe on a continual basis in a variety of situations-class discussion, playground interaction, encounters between classes. It was originally developed by the San Jose Area Bilingual Consortium and has undergone revision with leadership from Bilingual Education Office of the California of Education.

The first category on the matrix, comprehension, refers to both speaking and listening comprehension because listening and speaking are intertwined. That one can not participate in a conversation if he does not understand what has been said. The matrix breaks the other aspects of oral langue into four categories: fluency, vocabulary, pronunciation, and grammar. The goal is that to approximate a native speaker. 
In this study, student's speaking skill was basically measured based on the five indicators in Students Oral Langue Observation Matrix (SOLOM). They are comprehension, fluency, vocabulary, and grammar. To know student's speaking skill, the writer provided them with seven guiding questions made based on the curriculum. Student's response was interpreted into the categories where the maximum possible total score in this rubric is 25 . Look at the table 3

Table 3: Score Interval for Speaking Skill

\begin{tabular}{|l|c|c|}
\hline No & Score Interval & Category \\
\hline 1 & $5-10$ & Poor \\
\hline 2 & $11-15$ & Fair \\
\hline 3 & $16-20$ & Good \\
\hline 4 & $21-25$ & Very good \\
\hline
\end{tabular}

The data from the test was analyzed by using t-test. Popham and Sirotnik (1973:124) state that t-test is used to determine just how great the difference between two means be for it to be judge significant. The writer used two-tailed t test to find out whether there is a statistically difference between the two groups, the experimental and the control group. To run the analysis the writer used SPSS program for windows.

\section{RESULT AND DISCUSSION}

Statistical Analysis on the Experimental Group

The result of pre and posttest in the experimental were compared by using paired sample $t$ test. The result showed that there was significant difference before and after the treatment in the experimental group. It proved that chessboard technique was able to promote students' speaking skill.

\section{Statistical Analysis on the Control Group}

The result of pre and posttest in the control were compared by using paired sample $\mathrm{t}$ test. The result showed that there was no significant difference before and after the treatment in the control group.

\section{Difference Analysis on the Experimental and Control Group}

The result of posttest of both group were compared by using independent sample $\mathrm{t}$ test. From the calculation there was significant difference on the scores between students in experimental and control group. It proved that chessboard technique was able to improve students' speaking skill.

Based on the finding, the researcher interpreted that after being given the treatment, the student's speaking skill in experimental group increased especially in terms of comprehension, fluency, and vocabulary. In the pretest, most students answered the questions from the researcher in short and limited sentences. The questions that required information from the short story also could not be answered correctly. It showed that student's comprehension about the short story was still poor. In contras, in the posttest, the writer found most students were able to answer the questions well. They could add more sentences and students were able to answer the questions well. They could add more sentences and information about the short story. In addition, the students seemed more confident in answering the questions 
because they have been used to talking by using English. It happened because they spent more time to speak and practice during the application of chessboard technique for about two months.

During the application of chessboard technique, the researcher mostly offered the short stories with the topic that suited student's daily jlives such as love, family, friendship, and so on. These topics were really helpful to stimulate and trigger students to talk and voice their opinions because the topics were related to their lives.

In addition, this condition also supported what Rosenblatt stated in her book Literature as Exploration (1938:30-31) as cited in Church (1997:71-77) that the special meaning and sub emerge association of the words and images in the text largely determine what the text tries to convey to the individual reader. To respond it, the readers should bring his or her personality traits, personal experiences, present needs and preoccupation, a particular mood of the moment, and particular physical condition. These would determine his or her response to the peculiar contribution of the text. The point is that the reader should involve his or her feeling, emotion, and experiences into the text so that he or she is able to understand what the text tried to convey and directly feel what was in the text.

The student's achievement also can be seen from the statistical analysis of paired sample t-test. For the experimental group, based on the calculation of paired sample $t-$ test of experimental group the researcher concluded that there was a significant difference in speaking skill before and after the treatment in experimental group. While in control group, the researcher concluded that there was not a significant difference in speaking skill before and after the treatment. It could be seen form the result of paired sample $t$ test in control group in which $t$ obtained was lower that $t$-table. The value of t-obtained was 1.167 at the significant level $\mathrm{p}<0.01$ in two-tailed testing with $\mathrm{df}=14$, the critical value of $\mathrm{t}$ table is 2.624 .

Based on the results of the questionnaire, the researcher was surprised that though the results of the posttest was satisfying, the researcher found seven students $(46,6 \%)$ who said that using chessboard in responding short story was quite difficult for them and eight students $(53,3 \%)$ said otherwise. Students who said chessboard technique was difficult because of their lack of English vocabulary and grammar. Meanwhile, students who said it was not difficult answered that they liked debate and discussion very much so that they were accustomed to give argument and statement. Though their English vocabulary mastery was not that much, they were eager and curious to speak in English.

From this finding, it could be inferred that even though students; scores increased, they still found problem using chessboards technique. From the questionnaire, the researcher could draw a conclusion that such problem faced up because in chessboard technique, students talked a lot in English while in English classroom itself students were not having much time to practice English. 


\section{CONCLUSION}

Based on the result of the study, responding to short story by using chessboard technique in developing student's speaking skill was very useful. It could be seen from the result of the posttest of students who were taught by using chessboard technique. They got better performance than those who were taught by using chessboard technique.

Furthermore, chessboard technique could stimulate and challenged students to express their opinions, feeling and though better than the conventional method. Moreover, the topics in short stories given by the researcher help students to bring their personal interest and emotions during the teaching process.

In conclusion, chessboard technique helps students improve their speaking skill as a matter of fact that there was a significant difference in English speaking achievement between students who were not taught by using this technique.

\section{REFERENCES}

Arikunto, Suharsisni. 1998. Prosedur Penelitian: Suatu Pendekatan Praktis. Jakarta: Rhieka Cipta.

Beiger, George R., and Gerlach, Gail J. 1996. Educational Research: A Practical Approach. USA: DelmarPublisher.

Collie, Joanne, and Slater, Stephen. 1987. Literature in the Language Classroom: A Resource book of ideas and activities. New York, NY: Cambridge University Press.

Homby, A. S. 1995. Advance Oxford Learner's Dictionary $5^{\text {th }} \mathrm{ed}$. Great Britain: Oxford University Press.

Kayi, Hariye. 2006. Teaching Speaking: Activities to Promote Speaking in a Second Language. Retrieve from http://itesjl.org/article/kayiteaching speaking. html. accessed on January 29 2009.

Lawtie, Fiona. 2004. Teaching Speaking Skills 2: Overcoming Classroom Problems Retrieve from http:/teachingenglishorg.uk/think/speak/speakskil 12. html. accessed on Dec 102007.

Sari, Devi Komala. 2006. The Difficulties in Speaking English on the Basis of the Second Year Students of SMAN 18Palembang.

Unpublished Undergraduate Thesis. Universitas Sriwijaya. Indralaya.

Veronica, Liza. 2008. Applying Social Perspective to Promote Literary. Appreciation of the Eleventh Grade of SMA Xaverius Palembang. Unpublished Undergraduate Thesis. Universitas Sriwijaya. Indralaya.

Webster, Meriam. 1984. Longman Dictionary of the English Language. New York, NY: Longman GroupUK. Limited. 